\title{
Development of Educational Programs in Renewable and Alternative Energy Processing: the Case of Russia
}

\author{
Anna Svirina $^{1}$, Olga Shindor ${ }^{2}$, Konstantin Tatmyshevsky ${ }^{3}$, \\ ${ }^{1-2}$ Kazan National Research Technical University, ${ }^{3}$ Vladimir State University
}

\begin{abstract}
The paper deals with the main problems of Russian energy system development that proves necessary to provide educational programs in the field of renewable and alternative energy. In the paper the process of curricula development and defining teaching techniques on the basis of expert opinion evaluation is defined, and the competence model for renewable and alternative energy processing master students is suggested. On the basis of a distributed questionnaire and in-depth interviews, the data for statistical analysis was obtained. On the basis of this data, an optimization of curricula structure was performed, and three models of a structure for optimizing teaching techniques were developed. The suggested educational program structure which was adopted by employers is presented in the paper.

The findings include quantitatively estimated importance of systemic thinking and professional skills and knowledge as basic competences of a masters' program graduate; statistically estimated necessity of practice-based learning approach; and optimization models for structuring curricula in renewable and alternative energy processing. These findings allow the establishment of a platform for the development of educational programs.
\end{abstract}

Keywords - education, eco-engineering, energy supply, curricula optimization.

\section{INTRODUCTION}

The Russian Federation (an efficiency-driven economy with a focus on natural resources processing [1]) is rated $56^{\text {th }}$ in the Climate Change Performance Index 2013 with a negative trend. This rating corresponds to one of the highest levels of emissions, poor emission development level, low energy efficiency, very low level of renewable sources implementation and low quality climate policies. Russia's neighbours, China and Kazakhstan, which suffer from the same problems, perform either relatively efficient policy in implementation of renewable resources (China) or effective climate policies (Kazakhstan). Moreover, currently not all Russians have access to electric power supply [2, 3]: in the first place in distant and northern regions (2/3 of Russian territory and $6.3 \%$ of population), but also inhabited rural territories of Central, North-Western, Ural and Siberian federal districts - that can be seen on space photos. Even if there is direct access to electric power supply an average rural consumer suffers 70-100 hours of shutdown annually (compared to 7-10 hours in developed countries), and for $35 \%$ of rural consumers, the average voltage falls down to $190 \mathrm{~V}-200 \mathrm{~V}$ every evening.

All of the above prove the importance of the development of mechanisms - ones aiming to create a connection to electrical power up for $100 \%$ of Russian households, taking into account, that it is very inefficient to continue to create electric power supply connections by using a centralized scheme (inherited from the Soviet Union); while a centralized provision of electric power may be efficient for cities and agglomerations, the rest of the country should be electrified with small energy producing units (and these are usually using renewable or alternative sources of energy). At the same time, existing policies provide guidelines for renewable and alternative energy use from both the European Union [4] and the Russian Federation [5].

In this paper we aim to evaluate the influence of a special educational program structure and educational policies on the trend of renewable and alternative energy development. This influence is estimated by processing data on educational policy changes in relation to renewable and alternative energy development on the basis of statistical instruments. Our empirical data comes from two relatively well-developed regions of Russia: Tatarstan Republic and Vladimirskaya oblast, and is acquired both from open source and deep interviewing of stakeholders.

To achieve this goal, we have adapted the practical-based approach suggested in existing literature [6], which insists on using a systemic framework for educational programmes development; defines boundaries and possibilities for experiential learning approach implementation in higher education [7]; estimates measuring instruments for evaluation of effectiveness and efficiency of higher education [8]; provides the platform for life-long learning and efficient postgraduate performance [9]; evaluates tools for efficient education of undergraduate students [10]. Justified guidelines for master programs development were provided by Bellanca [11], who provided proof on the necessity to apply practical skills in the contemporary curriculum; Godinho and Schrimption [12], who outlined the importance of multidisciplinarity in building competences; and Parsons and Beauchamp [13], who developed an algorithm for competence building within a master course. However, all of this literature, on the one hand, does not pay strict attention to combining mentioned approaches in order to create a master program within environmental processing sphere, which is in the focus of this study, and, on the other hand, it does not analyze correlation between teaching techniques implemented in the curriculum and graduates' performance in the workplace, which is provided in this study. 


\section{IMPLEMENTED METHODOLOGY}

To start the analysis within this paper, we used the questionnaire distribution which covered the main competences that an employee should have in the employers' opinion. Development of the questionnaire was based upon existing research in competence-based learning [14, 15, 16, 17]. The questionnaire included 9 questions (some of them, such as evaluating competences, were complex), and it was distributed between 49 managers of real economy sector companies. $43 \%$ of the companies were industrial enterprises - and it was described in detail by Suslova [18]. The results acquired with the questionnaire were evaluated with the use of factor analysis in SPSS Statistics, which helped to reveal the main competences valued by the employers in the field of renewable and alternative energy processing masters in a fiveyear interval.

According to the revealed needs of employers, we have evaluated the proposed curriculum and teaching approach by succeeding questionnaire with in-depth interviews (we used regular methodical approach in in-depth interviews [19]) with the educational process stakeholders. The method of evaluation was the following: respondents were provided with the curriculum outline, including competences provided within each of the suggested courses (with corresponding teaching approaches). Respondents evaluated the courses themselves, suggested competences and teaching approaches with a 7-point Likert scale (1 meant "absolutely irrelevant", 7 - "absolutely relevant"). On the basis of this evaluation we developed the adjusted curricula which were again evaluated by the external experts with the same scale. We have chosen this method because, as it was proven by Schwarz and Deutsch [20], this type of scale provides better evaluation of respondents' answers, which was necessary to achieve the goals of this study.

Median was used to obtain average values, and it was calculated in the following way:

$$
M e=X_{\mathrm{Me}}+h_{\mathrm{Me}} \frac{\frac{\sum m}{2}-S_{\mathrm{Me}-1}}{m_{\mathrm{Me}}},
$$

$X_{\mathrm{Me}}, h_{\mathrm{Me}}-$ lowest value and range of median interval accordingly; $\sum m / 2$ - half of total observations; $S_{\mathrm{Me}-1}-$ number of observations before median range; $M_{\mathrm{Me}}-$ number of observations within the median range.

After calculation of the averages we carried out a correlation analysis on the basis of data provided by partner enterprises of Kazan National Research Technical University and Vladimir State University and was evaluated by SSPS Statistics software. This type of software was chosen as one of the most widespread in existing social research.

\section{RESULTS AND DISCUSSION}

On the pre-analytical stage of the master program in renewable and alternative energy evaluation we have found out, that existing level of environmental dynamics and uncertainty in Russian Federation requires redesigning master's training profiles towards multidisciplinary education. Teaching specialists eco-engineering techniques is one of the clearest examples of multidisciplinary approaches in education. In this case the training modules need to include the following topics: energy efficient production, renewable energy sources, secondary energy sources, economics and management. Henceforth it is necessary to develop an interdisciplinary master program in the sphere of environmental processing and sustainable use of renewable recourses and bio-waste to implement best practices in this area in the field of higher education. This program should imply a balanced approach to master's education, when equal attention is paid to the problems of technique and technology that are used for: environmental processing, energy efficiency, renewable energy implementation, environmental safety, derivatives (such as power-heat-cooling coupling) and managerial, sustainable development-based decision-making. At the pre-stage of program development we have revealed that existing implemented and developed corresponding programs (at Kazan National Research Technical University and Vladimir State Technical University) possessed rigorous focus on either ecological/environmental aspects or renewable resources energy processing. However, current market demand for experts in all three spheres (the ones defined as sustainable energy development), i.e. a structural engineering mix of environmental and renewable energy processing based upon energy efficient solutions; and this program has to be developed to achieve a new level of environmental processing education in Russia - within the framework, provided by legal documents and approved energy strategy [4].

The master program which achieved the above mentioned guidelines was developed as a joint program of Kazan National Research Technical University and Vladimir State University, the two Russian universities of TEMPUS consortium of "Eco-Engineering - environmental processing and sustainable use of renewable recourses and bio-waste" project (implemented in 2011-2014). On the first stage we evaluated required competences by distributing a questionnaire between Tatarstan Republic and Vladimir oblast employers, which are long-term partners for the above mentioned universities. The results of the evaluation of questionnaires in terms of competences, preferable to employers, are present in Fig. 1.

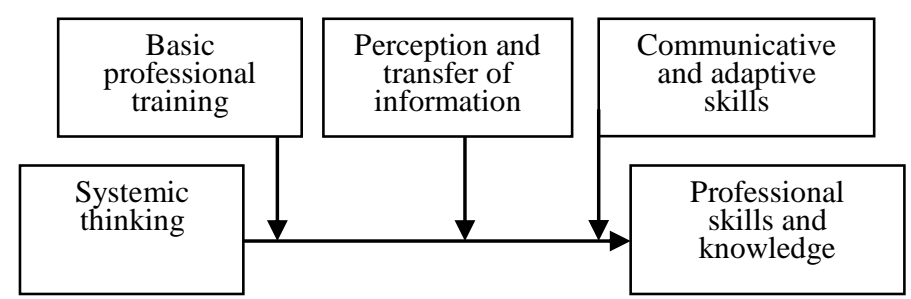

Fig. 1. Moderating and basic competences model (mid-term future evaluation).

As it can be seen from Fig. 1, in the mid-term future the main competences valued by employers (according to questionnaire evaluation and testing for statistical significance by SPSS Statistics for the suggested model Cronbach's alpha 
is equal to 0.935 which means the results are significant [21]) are systemic thinking and professional skills and knowledge.

Employers' evaluation of systemic thinking and professional skills/knowledge mega-components in the proposed model are featured in Table 1, which provides rotated components evaluation matrix that introduces the level of significance for each factor. This Table 1 features coefficients on a scale 0 to 1 , where 0 means total absence of statistical significance of a factor, while 1 means the factor is absolutely significant.

TABLE I

COMPETENCE Model For MID-Term Future

\begin{tabular}{|l|c|c|}
\hline \multicolumn{1}{|c|}{ Skills and knowledge } & $\begin{array}{c}\text { Systemic } \\
\text { thinking }\end{array}$ & $\begin{array}{c}\text { Professional } \\
\text { skills }\end{array}$ \\
\hline $\begin{array}{l}\text { Is able to define reasons and } \\
\text { consequences }\end{array}$ & 0.939 & \\
\hline $\begin{array}{l}\text { Can see a problem under different } \\
\text { angles }\end{array}$ & 0.879 & \\
\hline $\begin{array}{l}\text { Can identify and structure the } \\
\text { problem }\end{array}$ & 0.799 & \\
\hline Has a large scope & 0.763 & \\
\hline $\begin{array}{l}\text { Is able to evaluate consequences of } \\
\text { hislher decisions }\end{array}$ & 0.792 & \\
\hline $\begin{array}{l}\text { Possesses the knowledge and skills of } \\
\text { necessary technical professional tools }\end{array}$ & & 0.976 \\
\hline $\begin{array}{l}\text { Is able to implement professional } \\
\text { computational instruments }\end{array}$ & & 0.976 \\
\hline $\begin{array}{l}\text { Has an ability to adapt theoretical } \\
\text { knowledge to practice }\end{array}$ & & 0.808 \\
\hline $\begin{array}{l}\text { Is ready to actively adopt new } \\
\text { technologies and techniques }\end{array}$ & & 0.791 \\
\hline Is ready for lifetime learning & & \\
\hline
\end{tabular}

As it can be derived from the table, the most important competences, considered by employers, are the abilities 1) to define reasons and consequences, 2) to acquire necessary knowledge and professional skills and 3) to implement professional instruments as well as ability to see a problem from different angles. These and other competences, mentioned in Table 1, were considered to define curricula structure as well as teaching techniques.

The program developed on the basis of employers' evaluation aims to form the most important of above mentioned competences, combines balanced elements of fundamental and applied science, engineering and managerial solutions practice, relevant natural sciences issues and real activities within small innovational enterprises that are established by higher educational institutions - as well as intensive internships in companies-employers. This design of curricula, which was structured by academicians and evaluated by employers, allows graduates to acquire sufficient professional competences in solving sustainable development problems on the single enterprise level, and as well on regional/national/international level - in the sphere of alternative and renewable energy. According to deep interviews, the competences developed in the master program of Kazan National Research Technical University and Vladimir State University, would be appropriate for the following employers: state structures responsible for institutional and direct regulation of industrial safety, environmental protection and real sector efficiency regulation; departments of personal safety and environmental protection; companies developing innovative ecological and/or renewable energy implementing energy efficient technique and technologies; project and research institutions; non-profit organization (including political ones) in cross-border exploitation of natural resources, environmental safety, renewable energy and coincidental applicable solutions.

This curriculum, which was designed on the basis of employers' evaluation and in accordance with the requirements of Russian educational standards, includes the following modules:

1) ecological component (sustainable development of production and consumption: theory, methodology and history; development and implementation of ecological technique and technology; ensuring environmental safety: regional and inter-regional level; legal regulation and framework; methods of estimation and modeling of environmental processing; ecological efficiency analysis of engineering solutions in environmental processing);

2) equipment building component (innovative equipment and methods of energy saving and energy conservation; decentralized and autonomous energy processing (technique and technology); energy efficient production based on renewable resources; measuring technique and technology for renewable resources processing and utilization; processing of integrated energy efficient engineering solutions; complex analysis of engineering solutions based upon renewable energy resources implementation);

3) economic and managerial component (financial provision of environmental processing and renewable energy technique and technology development, implementation and use; organizational provision of environmental processing and renewable energy technique and technology development, implementation and use).

Within this structure each of the assigned sub-modules aims to develop a certain set of competences. Henceforth, some of the courses were approved as presented by academics (for example, "Technical measures in power engineering" with the following competences: willingness to develop the program of experiments studies and tests, make measurements with a choice of modern technical means and process of measurement results, ability to select a device and make measurements with a given accuracy, ability to exercise metrological support of measurements), while some of the others had been evaluated and restructured by the employers as a result of evaluation and in-depth interviewing (for example, "Alternative and renewable sources of energy", where employers outlines as necessary the following competences: ability to recognize the main problems in the field of renewable and alternative energy, ability to operate the objects of alternative energy, ability to choose new methods and tools for the implementation of alternative energy projects, willingness to generate and use new ideas on the application of the alternative energy).

On the basis of a two-stage evaluation by alternative energy sphere employers and equipment building employers (main ones for both Kazan National Research Technical and 
Vladimir State universities), the following set of courses was approved for the designed joint master program:

- Information technology in constructing building;

- Mathematical modeling in systems devices;

- Information-measuring systems in power engineering;

- Life cycle approaches in alternative energy;

- $\quad$ Electric power supply of technical equipment :

- Theory and practice of energy supply;

- Alternative and Renewable sources of energy;

- Modern energy technologies;

- Techniques and Technology of a scientific experiment;

- Technical measurements in power engineering;

- Economic and organizational issues of ecological engineering.

The suggested list of courses was adjusted to the requirements for educational standards and at the same time was approved by the main customers - employers (this was a part of TEMPUS project in a work package "Quality", task "External evaluation").

Finally, the list of preferable teaching techniques was developed within the described two-stage evaluation process. According to this process, practical orientation was approved to be the basic educational approach for developed curriculum. Since this program was designed for students who already have their first academic degree, and considering the importance to implement strong linkage to practice, Kazan National Research Technical University and Vladimir State University have suggested the following pedagogical approach in order to achieve the objectives:

1) resource-based learning, i.e. mostly virtual/PC simulations and experimental modeling of industrial situations. In order to achieve this goal we suggest the introduction of modeling the processes in the LabView virtual environment in a number of suggested courses;

2) case-based learning, including special cases for the Russian Federation. To achieve this goal we defined the necessity to evaluate and study the legal framework and institutional environment for alternative energy power processing implementation;

3) project-based learning, i.e. group projects including interdisciplinary ones. This approach has to be used both during company internships, and within course projects to ensure students' abilities for teamwork;

4) learning-by-doing, i.e. student employment in innovational SME's established by universities on rotational bases under academic and practical supervision. Within this learning approach at the moment a few business plans were developed, and some of them received investors' approval after presentation in business plan competitions, which enriched educational process.

Teaching materials, developed within this learning approach, present a balanced mix of theory and indispensable part of practical references. Specific tools are provided to help students and teachers capture formative and essential information about student's learning and performance, including reflection questions, checklists, rubrics, open project forum, feedback from teachers and students is planned in project activities. The learning process has to be accompanied by multi-media ICT infrastructure, i.e. computer modeling,
Internet researches, online case studies, and by special laboratory equipment (power aggregates and its elements, test stations, etc.). Special focus will be placed on a module that structures and introduces the ECTS system. By using it we promote students' mobility between Kazan National Research Technical University and Vladimir State University.

Employers' average satisfaction with the developed curriculum and corresponding teaching approaches suggested on the first and second stage of evaluation can be found in Fig. 2 (average satisfaction on 7-point Likert scale where 1 equals "completely dissatisfied" and 7 - "completely satisfied").

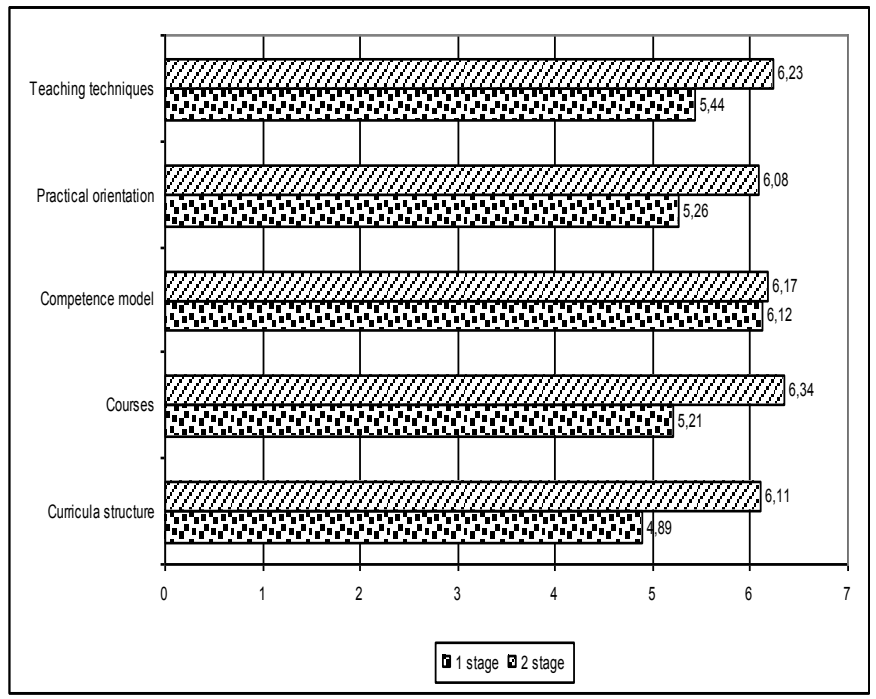

Fig. 2. Evaluation of developed curricula.

As it can be seen from Fig. 2, at the second stage of evaluation employers became satisfied with the structure, competence model and teaching techniques provided in the course, and approved the suggested approach for partner universities.

For the purpose of this study we have also carried out analysis of correlation between the quality of learning approaches used within the process of education, and the level of employee's efficiency on the basis of data provided by ten partner companies of the universities. Evaluation of teaching techniques was carried out at the universities (by rating each technique on 7-point Likert scale, where 1 means "the technique is not used, and 7 - this is a basic technique used within educational process), while evaluation of employees performance was provided as average level for $4-7$ employees, who graduated from this university. The results of correlation analysis (Pearson correlation) are presented in Table II.

TABLE II

PEARSON CORRELATION BETWEEN TyPES OF EdUCATIONAL TOOLS AND EMPLOYEE'S PERFORMANCE

\begin{tabular}{|c|c|c|c|c|}
\hline \multirow[b]{2}{*}{$\begin{array}{c}\text { Educational } \\
\text { technique }\end{array}$} & \multicolumn{4}{|c|}{ Results of employee's performance } \\
\hline & $\begin{array}{l}\text { Time } \\
\text { Losses }\end{array}$ & $\begin{array}{l}\text { Defects } \\
\text { Share }\end{array}$ & $\begin{array}{c}\text { Unenforced } \\
\text { Mistakes Share }\end{array}$ & $\begin{array}{c}\text { Labour } \\
\text { Effectiveness }\end{array}$ \\
\hline Lectures & 0.304 & 0.327 & -0.133 & -0.425 \\
\hline Laboratory works & $-0.763^{*}$ & -0.591 & $-0.651^{*}$ & $0.733^{*}$ \\
\hline Simulations & -0.341 & -0.416 & 0.142 & 0.391 \\
\hline Internships & $-0.656^{*}$ & $-0.774^{* * *}$ & $-0.695^{*}$ & $0.696^{*}$ \\
\hline Projects & -0.084 & -0.189 & 0.389 & 0.284 \\
\hline
\end{tabular}

$*$ Correlation is significant at 0.05

**Correlation is significant at 0.01 
As it can be derived from Table II, lecturing does not affect employee's performance, and the same is true for projects and simulations. This can be explained by the nature of these educational activities - simulations in many cases are not a good model of real life, while projects involve teamwork, and some of the team members are not making any significant contribution. Thus, to achieve higher quality of education in the field of renewable and energy processing (the employees in the sample were involved in the area for their enterprises) these educational approaches can be used, but they become a subject of gradual replacement, or change of approaches (for instance, projects were redesigned by partner universities in this TEMPUS project [22]). At the same time other types of educational techniques seem to have a relatively high impact on employee performance in the future. This can be explained by the fact, that in laboratory works and internship, students are getting on-hand experience. Henceforth, providing a significant amount of laboratory works allows reducing time losses and unenforced mistakes in the future, and also leading to higher labour effectiveness. Internships are strongly correlated with all four indicators of employee's efficiency, and this educational technique has the most influence on defects share of employee-developed products, and that means that internships, even internships in SME's on a rotational basis, would allow ensuring a higher quality of education. These findings also correlate with the findings of partner universities of the mentioned TEMPUS project, which reveal the necessity to implement a learning-by-doing approach [22].

The same mutual relations were tested by using nonparametric correlations which can be found in Table III.

\section{TABLE III}

NON-PARAMETRIC CORRELATION BETWEEN TYPES OF EDUCATIONAL TOOLS AND EMPLOYEE'S PERFORMANCE

\begin{tabular}{|c|c|c|c|c|}
\hline \multirow[b]{2}{*}{$\begin{array}{l}\text { Educational } \\
\text { technique }\end{array}$} & \multicolumn{4}{|c|}{ Results of employee's performance } \\
\hline & $\begin{array}{l}\text { Time } \\
\text { Losses }\end{array}$ & $\begin{array}{l}\text { Defects } \\
\text { Share }\end{array}$ & $\begin{array}{l}\text { Unenforced } \\
\text { Mistakes } \\
\text { Share }\end{array}$ & $\begin{array}{l}\text { Labour } \\
\text { Effectiveness }\end{array}$ \\
\hline $\begin{array}{ll} & \text { Lectures } \\
\end{array}$ & 0.289 & 0.111 & -0.156 & -0.244 \\
\hline ( Laboratories & $-0.689^{* *}$ & -0.422 & -0.333 & $0.644^{* *}$ \\
\hline Simulations & $-0.689^{* *}$ & $-0.778^{* *}$ & -0.156 & $0.733^{* *}$ \\
\hline D Internships & $-0.539^{*}$ & $-0.719^{* *}$ & -0.360 & $0.584^{*}$ \\
\hline$\forall \cup \longdiv { \text { Projects } }$ & -0.156 & -0.244 & 0.289 & 0.200 \\
\hline$=$ Lectures & 0.394 & 0.248 & -0.309 & -0.382 \\
\hline ฮี อี Laboratories & $-0.782^{* *}$ & -0.515 & -0.503 & $0.721^{*}$ \\
\hline Simulations & $-0.842^{* *}$ & $-0.891^{* *}$ & -0.261 & $0.855^{* *}$ \\
\hline I & $-0.650^{*}$ & $-0.851^{* *}$ & -0.486 & $0.675^{*}$ \\
\hline क 8 Projects & -0.285 & -0.321 & 0.370 & 0.345 \\
\hline
\end{tabular}

*Correlation is significant at 0.05

**Correlation is significant at 0.01

Correlation analysis in Table III proves the absence of correlation between implementation of lecturing and projects as an educational techniques, but reveals that three other techniques have a significant impact on future employee performance (unlike in case of Pearson correlation analysis). This might be explained by the nature of Spearman's and Kendall's correlation: since it is a rank correlation, the fact that lecturing and projects, if done as necessary, provide better understanding of the process. As a result, employees, who analyzed lectures and participated in projects, show better performance, and it is recorded by rank correlation. Thus, simulations proved to influence a reduction in employee's time losses, defects share and increase in labour effectiveness, and this correlation appeared to be significant at 0,01 (that means results are reliable). The same results are achieved by both Kendall's and Spearman's coefficients. Internships influence all three same indicators of employee's performance as well. Finally, laboratory works have a significant impact on reduction of time losses and growth of labour effectiveness. Reduction of unenforced mistakes share can be affected by using laboratory works and internships, but this finding is not proved by non-parametric analysis. These techniques are to be used broadly in master programs, but they do not necessarily lead to a significant gap in education quality.

In order to evaluate the significance of different educational tools in terms of providing better employee performance in the future, we have also used factor analysis [20] (see Table IV for results).

TABLE IV

FACTOR ANALYSIS OF LABOUR EFFECTIVENESS

\begin{tabular}{|l|l|c|}
\hline \multicolumn{2}{|l|}{ Indicator } & Predicted factor: labour effectiveness \\
\hline Correlation & Laboratory works & 0.733 \\
\cline { 2 - 3 } & Simulations & 0.391 \\
\cline { 2 - 3 } & Internships & 0.696 \\
\cline { 2 - 3 } & Lectures & -0.425 \\
\cline { 2 - 3 } & Projects & 0.284 \\
\hline
\end{tabular}

The data in Table IV proves the above stated conclusion that the most important learning techniques in terms of providing future high labour effectiveness are laboratory works, and internships, but at the same time according to the model lectures should not to be excluded from the educational process as a third significant factor that corresponds to future employee performance.

These findings support the idea that, in order to provide high quality education in the field of renewable and alternative energy processes, a mixture of laboratory works, simulations and internships is to be used, and this is the approach which was chosen by Kazan National Research Technical and Vladimir State universities to create such educational programs.

On the basis of these results a predictive model for teaching techniques optimization was created for the three dependent variables: labour effectiveness, time losses of an employee and defects share in the product line produced by an employee. In case of labour effectiveness determination coefficient of a linear regression model is estimated at 0.794 that proves relatively high accuracy of the model. ANOVA analysis had also proved relatively high accuracy of the model. This result is also supported by estimated value of corrected determination coefficient. Coefficients of the model are presented in Table $\mathrm{V}$.

As it can be seen from Table V, to achieve future labour efficiency, universities should stress the importance of simulations and internships, and these are the main teaching techniques that are to be used in the curriculum. At the same time, in order to provide a balanced educational program, laboratory works are to be included in the developed curriculum as well. This seems logical, since future labour 
efficiency mainly relates to the experience - which is gained by students mainly during internships and simulations. Labour efficiency is usually the main indicator monitored by an employer, and henceforth universities should put more emphasis on internships and simulations in their curriculum.

TABLE V

LABOUR EFFeCtiveness Model NON-STANDARDIZED AND STANDARDIZED COEFFICIENTS

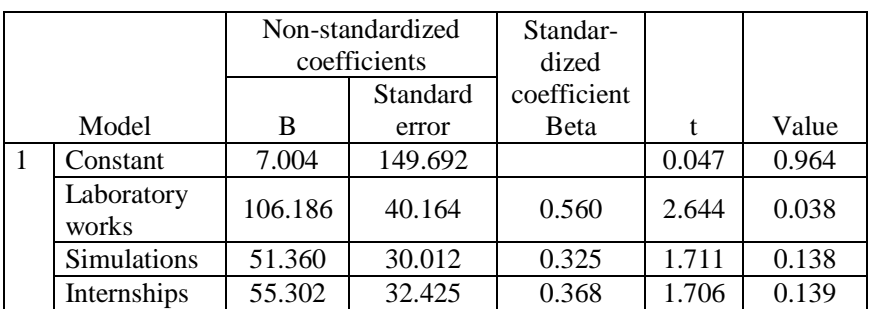

Dependent variable: Labour Effectiveness (thousands of monetary units per person)

Independent variables: Laboratory works, Simulations, Internships (frequency of use)

In the linear model for time losses estimation that was developed for the purposes of this research, has determination coefficient of this model is 0.771 , that together with the results of ANOVA analysis proves relatively high accuracy of the developed model. This result is also supported by estimated value of corrected determination coefficient. Coefficients of the linear model are shown in Table VI.

TABLE VI

Time Losses Model Nonstandartized AND STANDARDIZED COEFFICIENTS

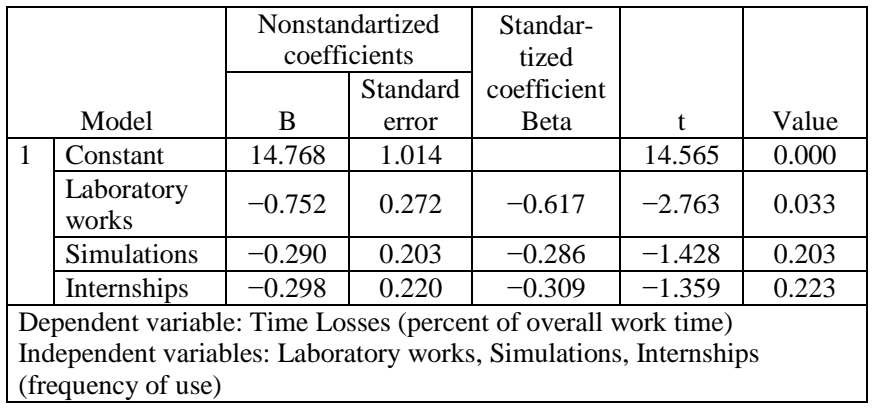

As one can see from Table VI, to reduce future employee time losses, a lot of time during the educational process should be dedicated to internships. This can be explained by the fact that time losses at the workplace mainly occurs when an employee does not have necessary experience at his or her workplace, and this experience can be gained through internships and simulations.

In the linear model for defects share estimation that was developed for the purposes of this research has determination coefficient of this model is 0.756 , that together with the results of ANOVA analysis proves relatively high accuracy of the developed model. This result is also supported by estimated value of corrected determination coefficient. Coefficients of the linear model are shown in Table VII.

As it can be seen in Table VII, in order to provide a smaller defects share in future employee performance, universities need to structure curriculum by making laboratory works and simulations the main teaching techniques. This is possibly due to the fact that laboratory works require professional skills, and the presence of such skills in a workplace reduces the number of defects produced by an employee.

\section{TABLE VII}

DEFECTS SHARE MODEL NON-STANDARDIZED AND STANDARDIZED COEFFICIENTS

\begin{tabular}{|c|c|c|c|c|c|c|}
\hline \multirow{2}{*}{\multicolumn{2}{|c|}{ Model }} & \multicolumn{2}{|c|}{$\begin{array}{l}\text { Non-standardized } \\
\text { coefficients }\end{array}$} & \multirow{2}{*}{$\begin{array}{l}\text { Standar- } \\
\text { dized } \\
\text { coefficient } \\
\text { Beta } \\
\end{array}$} & \multirow[b]{2}{*}{$\mathrm{t}$} & \multirow[b]{2}{*}{ Value } \\
\hline & & $\mathrm{B}$ & $\begin{array}{c}\text { Standard } \\
\text { error }\end{array}$ & & & \\
\hline \multirow[t]{4}{*}{1} & Constant & 21.350 & 1.528 & & 13.974 & 0.000 \\
\hline & $\begin{array}{l}\text { Laboratory } \\
\text { works }\end{array}$ & -0.582 & 0.410 & -0.327 & -1.421 & 0.205 \\
\hline & Simulations & -0.464 & 0.306 & -0.313 & -1.516 & 0.180 \\
\hline & Internships & -0.789 & 0.331 & -0.559 & -2.383 & 0.055 \\
\hline
\end{tabular}

Dependent variable: Defects Share (percent of overall work time)

Independent variables: Laboratory works, Simulations, Internships (frequency of use)

On the basis of the models, proposed universities can provide an optimal structure of educational processes in terms of providing balance between implementation of laboratory works, simulations and internships. For the purpose of curricula structure optimization it is necessary to define which indicator of employees' performance is the most important for the employer, and then apply the corresponding model to optimize structure of teaching techniques. As our evaluation of the employer's opinions had shown, for partner enterprises labour effectiveness is the main indicator to measure employee performance, and henceforth we recommend using model of labour effectiveness, which is presented in Table V. Such an approach would allow providing high quality education in the field of renewables and alternative sources of energy processing, and it is implemented in Kazan National Research Technical University and Vladimir State University.

\section{CONCLUSIONS}

The proposed curricula did not only receive approval by the main employers, but had also defined the basic problem of perception in renewable and alternative energy processing education in Russia. According to the results of in-depth interview, employers are mainly interested in the development of systemic-based professional competences which would allow university graduates to be efficient both in the development of complex solutions in the field of alternative energy and in developing solutions that rely on idea of small local energy supply approach instead of existing highly centralized one. The latter can only be based upon understanding the Russian energy environment where providing power supply within a centralized system is economically inefficient - and henceforth require specialist who can develop energy solutions that can be replicated by others.

The second finding arising from the research in development of curricula and teaching techniques was a strong focus on practical and action-based learning as the only tool that would allow to develop alternative and renewable based technologies despite the fact Russian policies are not 
providing necessary incentives of energy saving and energy efficiency.

Within the paper an evaluation of developing curricula provided employers with a better understanding of nature and possibilities of renewable and alternative energy and inspired a few relevant projects in Tatarstan and Vladimir. By means of correlation analysis it was proved that internships, laboratory works and simulations are teaching techniques that influence indicators of highly efficient employee performance the most. In the paper a few models for educational techniques structure optimization was suggested, and this model allows finding and implementing the balance of lecturing (which importance was proved by factor analysis), internships, simulations and laboratory works in order to provide maximum future employees' labour effectiveness, minimum losses of time and defects. According to the results of interviews which were carried out by Kazan National Research Technical University and Vladimir State University in the partner enterprises, employers insist on using curricula optimization model where labour effectiveness is used as a dependent variable (while intensity of laboratory works, internships and simulations implementation, rated on 7-point Likert scale are used as a dependent variables). Henceforth it is recommended to use this model in order to ensure high quality education in the field of alternative energy and renewables processing by achieving teaching techniques balance.

\section{REFERENCES}

1. GEM 2013 Global report. [Accessed: 13.04.2014]. Available: http://www.gemconsortium.org/ docs/3106/gem-2013-global-report

2. Kudrin, B. New electrification. Independent newspaper, 26.04.2006. Available: http://www.ng.ru/science/2006-04-26/14_electrification.html

3. Tarasov, A. Are the real reasons of catastrophe revealed? Novaya gazeta, 2013, Vol. 141, p. 8.

4. UNECE Strategy for Education for Sustainable Development. [Accessed: 13.04.2014]. Available: http://www.unece.org/fileadmin/ DAM/env/documents/2005/cep/ ac.13/cep.ac.13.2005.3.rev.1.e.pdf

5. Russian Federation energy strategy to 2030. [Accessed: 13.04.2014]. Available: http://minenergo.gov.ru/aboutminen/energostrategy/

6. Holaday, B., Weaver, K., Nilson, L. Revisioning graduate professional development programs. [Accessed: 13.04.2014]. Available: http://www.tandfonline.com/doi/abs/10.3200/

CTCH.55.3.99-103\#.U7 VB SEBBq40.

7. Kolb, A., Kolb, D. Learning styles and learning spaces: enhancing experiential learning in higher education. Academy of Management learning and education, 2005, Vol. 4, No. 2. pp. 193-212. http://dx.doi.org/10.5465/AMLE.2005.17268566

8. Keeton, M., Shekley, B., Griggs, D. Efficiency and effectiveness in higher education. Dubuque: IA. Kendall/Hunt publishing company, 2002.

9. Mentkowski, M. Learning that lasts: Integrating learning, development and performance in college and beyond. San Francisco: Jockey Bass, 2000.

10. Summers, L. On undergraduate education. Harvard magazine, JulyAugust 2003, pp. 63-65.

11. Bellanca, J. Enriched learning process: a practical pathway to 21 century skills. Bloomington, IN: Solution tree press, 2010.

12. Godinho, S., Schrimpton, B. Interdisciplinary curriculum: a sustainable future or unattainable vision in a changing educational climate. Available: http://www.aare.edu.au/08pap/god08708.pdf

13. Parsons, J., Beauchamp, L. From knowledge to action: shaping the future of curriculum development in Alberta. [Accessed: 23.03.2014]. Available: http://www.education.alberta.ca/media/6808607/

knowledge_action.pdf
14. Vasilyeva, E. Employers' satisfaction with the quality of graduate's education within the high tech sector. [Accessed: 07.02.2014]. Available: http://ecsocman.hse.ru/data/ 2011/04/05/1268020056/2010-4-3.pdf

15. Gaynanov, D., Gallyamov, R., Nagimov, R. Retrospective survey of balance in case of regional labour markets: analysis and prognosis. Contemporary problems of science and education, 2012, Vol. 6. pp. 458-467.

16. Kauffman's State of Entrepreneurship Address 2011. [Accessed: 12.02.2011]. Available: http://www.kauffman.org/uploadedfiles/ soe_address_2011.pdf

17. Monitoring of employers' satisfaction with graduates' education quality. Report. [Accessed: 07.01.2014]. Available: http://job.susu.ac.ru/doc/ report_mon.pdf

18. Suslova, O., Svirina, A. Investigation of structure and dynamics in employers' requirements for competences of university graduates. Obrazovanie i obschestvo, 2014, Vol.3, pp. 93-98.

19. Pereira, A., Pedrosa, T., Simon, K., Matovelle, A. In-depth interviews. [Accessed: 07.01.2014]. Available: http://www.ivm.vu.nl/en/Images/ PT8_tcm53-161513.pdf

20. Schwarz, N., Deutsch, B. Response scales: effects of category range on reported behavior and comparative judgment. Public opinion quarterly. 1985, Vol. 49, pp. 308-395. http://dx.doi.org/10.1086/268936

21. SSPS. Cleaning your data. [Accessed: 22.03.2014]. Available: http://wps.pearsoned.com.au /wps/media/objects/8264/8462810/Wilson _Cleaning.pdf.

22. Blumberga, D., Dace, E., Ziemele, J., Koshkin, I., Habdullina, Z. Experience of students' and teachers' pilot training in the field of environmental engineering in a post-soviet country. Environmental and climate technologies conference proceedings, RTU Press, 2013. pp. 17-22.

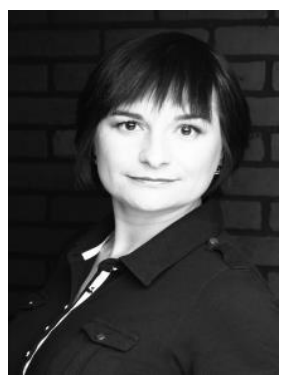

Anna Svirina has graduated from Kazan State Technical University in 2001. In 2005 she was awarded the degree of candidate of economic sciences, in 2012 - doctor of economic sciences. She is currently Head of the economics and management department of Kazan National Research Technical University, Kazan. Her background includes employment as an Accountant, Sales manager, Business plan consultant and CEO of travel agency.

Address: Adoratskogo street 15-82, 420126, Kazan, Russia.

Phone: 007-9172759292 Fax: 007-8434254269

E-mail: anna_svirina@yahoo.com

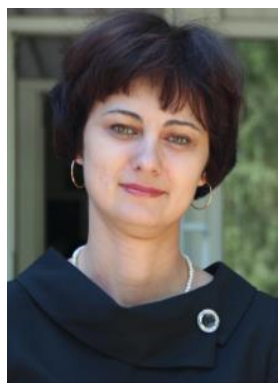

Phone: 007-9270301549

E-mail: o_v_sh@mail.ru

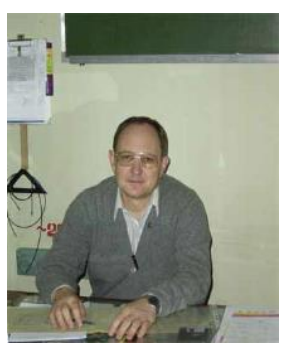

Olga Shindor is a PhD student in the Institute of Radioelectronics and Telecommunications, Kazan National Research Technical University. She works in the autonomous campus "Vostok" of this university. Her main field of interest is data processing with wavelet transform; systems of technical diagnostic, renewable energy, prediction the state of equipment bases on the wavelet transform the signal of this equipment.

Address: Engels street 127a, 422981, Chistopol, Tatarstan Republic, Russia.

Konstantin Tatmyshevsky is a doctor of technical sciences at Vladimir State University. $\mathrm{He}$ is Head of the equipment building and informational and management technologies department at Vladimir State University.

His main field of interest is equipment building in military production complex, technical management systems.

Address: Gorkogo street, 87, 600000, Vladimir, Russia.

E-mail: tatmysh@mail.ru 